\title{
Tıp fakültesi öğrencilerinin çocukluk yaş grubunda ateşle ilgili bilgi ve tutumlarının
}

\section{değerlendirilmesi}

Osman Sami AKMAN ${ }^{1}$, Akın TORUN ${ }^{1}$, Engin AYDIN², Mustafa BÜYÜKAVCI ${ }^{2}$

\begin{abstract}
$\ddot{\mathbf{O z}}$
Cocuklarda vücut sıcaklığı farklı tekniklerle ve farklı yerlerden ölçülmekte ve bu da değerlendirmeyi etkilemektedir. Biz bu çalışmada, tıp fakültesi öğrencilerinin çocuklardaki ateş ölçüm yöntemleri ve bunların değerlendirilmesiyle ilgili bilgi ve tutumlarını değerlendirmeyi amaçladık. Tıp Fakültesi’nde öğrenim gören 96 öğrenciye ikili görüşmeyle 10 soruluk bir anket uygulandı. İlk 4 soru vücut sıcaklığ ateş tanımı ile, son soru da ateşli çocuğa yapılacak ilk girişimle ilgili idi. Öğrencilerin \% 44,8'i (43 kişi) çocuklarda vücut sıcaklığını ölçerken dijital termometre kullandığını belirtirken, 10 (\% 10.4) öğrenci civalı, 10 öğrenci infrared (alından) termometre kullandığını ifade etti. Hangi termometrenin vücut 1sısını daha doğru ölçtüğü sorusuna öğrencilerin 31 'i dijital, 24'ü infrared ve 16's1 civalı termometre cevabını verirken 19'u bu konuda fikri olmadığını söyledi. Öğrencilerin yarıya yakını (\% 42,8) ateş demek için çocuklarda vücut sıcaklığının üst sınırı olarak $37.5^{\circ} \mathrm{C}$ 'yi kabul etmekteydi. Yirmi kişi $(\% 20,8) 37^{\circ} \mathrm{C}, 15$ kiși $(\% 15,6) 38{ }^{\circ} \mathrm{C}$ ve 12 kişi de $(\% 12,5) \quad 36.5{ }^{\circ} \mathrm{C}$ 'yi ateş sınırı olarak belirtmişti. Katılanların \%76'sı vücut sıcaklığının ölçüldüğg̈ yere göre değiştiğini, \%18,8'i ise değişmediğini belirtmekteydi.Yüksek ateş saptanan çocuğa ilk müdahale olarak öğrencilerin \% 80'den fazlası giysileri çıkarma, ılık suyla duş veya alın-koltuk altına pansuman önerirken, antipiretik ilaç veren veya soğuk suyla duş öneren hemen hemen yoktu. Sonuç olarak, tıp fakültesi öğrencilerinin önemli bir kısmının çocuk hastalarda vücut sıcaklığının ölçüm tekniği, değerlendirilmesi ve yönetimi konusundaki bilgi ve tutumlarının yetersiz olduğu gözlendi.
\end{abstract}

Anahtar Kelimeler: Çocuk, vücut 1sısı, ateş, öğrenci, bilgi

Yayın Bilgisi

Gönderi Tarihi:15.08.2018

Kabul Tarihi:20.10.2018

Online Yayın Tarihi:31.03.2019

DOI: $10.26453 /$ otjhs. 453182

Sorumlu Yazar

Mustafa BÜYÜKAVCI

Assessment of the knowledge and attitudes of medical school students about fever in children

Osman Sami AKMAN ${ }^{1}$, Akın TORUN ${ }^{1}$, Engin AYDIN ${ }^{2}$, Mustafa BÜYÜKAVCI ${ }^{2}$
Article Info

Received:15.08.2018

Accepted:20.10.2018

Online Published:31.03.2019

DOI: $10.26453 /$ otjhs. 453182

Corresponding Author

Mustafa BÜYÜKAVCI participants had no idea about accurate type of thermometers. Almost half of the students (42.8\%) considered a temperature of more than $37.5^{\circ} \mathrm{C}$ to be a fever in children. Twenty (20.8\%), $15(15.6 \%)$ and $12(12.5 \%)$ persons believed that $37{ }^{\circ} \mathrm{C}, 38{ }^{\circ} \mathrm{C}$ and $36.5{ }^{\circ} \mathrm{C}$, respectively, were the upper limit of normal body temperature. Body temperature varies at different sites of temperature measurement according to $76 \%$ of the students, however, $18.8 \%$ believed that it is constant in all sites. Although more than $80 \%$ of students suggested removing clothes, warm water bath or tepid sponging on forehead and axilla as a first step in the management of a febrile child, almost no one was suggesting to give antipyretics or cold water bath. In conclusion, the majority of medical school students had inadequate knowledge and attitudes on temperature measurement methods, and evaluation and management of fever in children.

Keywords: Child, body temperature, fever, students, knowledge

${ }^{1}$ Sakarya Üniversitesi Tıp Fakültesi Öğrencisi, Sakarya

${ }^{2}$ Sakarya Üniversitesi Tıp Fakültesi, Çocuk Sağlığı ve Hastalıkları AD, Sakarya 


\section{GíRiș}

Vücut sıcaklığının anormal yükselmesi olarak tanımlanan ateş, acil servislere başvuran çocukların yaklaşık \%30'unda saptanan en yaygın yakınmalardan birisidir. ${ }^{1}$ Ateşin saptanması için vücut sıcaklığının ölçümü fizik muayenenin önemli bir parametresidir. Vücut sıcaklığının sağlıklı ölçülebilmesi için uygun yerden ve doğru teknikle ölçüm yapılması gerekmektedir. Yanlış ölçüm yapılması ya da ölçüm sonucunun yanlış yorumlanması, altta yatan hastalığın tanı ve tedavisinde gecikmelere yol açacaktır.

İdeal bir vücut sıcaklığı ölçüm tekniği güvenilir, kolay uygulanabilir, noninvaziv ve ucuz olmal, ayrıca iç (core) vücut sıcaklığını (göğüs ve baştaki iç organların sıcaklığı) yansıtmalıdır. Birçok ölçüm metodu olmasına rağmen bu kriterlerin hepsini sağlayan bir teknik maalesef yoktur. ${ }^{2}$ Rektal ölçüm iç vücut sıcaklığını ölçmek için altın standart olarak kabul edilmesine rağmen bazı dezavantajlarından dolayı kullanımı yaygın değildir. ${ }^{3}$ Ülkemizde, vücut sıcaklığı ölçümü için günlük pratikte en çok kullanılan yerler aksilla, rektum, alın (temporal arter) ve timpanik membrandır. Sağlık hizmeti veren kurumlarda, timpanik membran veya alından ölçüm yapan infrared termometrelerin kullanımı giderek artmaktadır. Ancak ailelerin çoğunluğu vücut sıcaklığını evde aksiller bölgeden ve dijital (elektronik) termometrelerle ölçmektedir.

Günlük pratikte, ailelerde olduğu kadar sağlik çalışanları arasında da vücut sıcaklığını ölçüm metodu ve ateş tanımı konusunda kafa karışıklığı olduğu gözlenmektedir. Biz bu çalışmada, tıp fakültesi öğrencilerinin çocukluk çağında vücut sicaklığı ölçüm metotları ve ateşin tanımı konusundaki bilgi ve tutumlarını araştırdık.

\section{MATERYAL VE METOT}

Çalışma kesitsel anket şeklinde planlandı ve Sakarya Üniversitesi Tıp Fakültesi öğrencisi olan iki araştırmacının katılımcılarla yüz yüze görüşmesi şeklinde uygulandı. Şubat 2015 ve Mart 2015 tarihleri arasında, Tip Fakültesi öğrencilerinden oluşan katılımcılara çoktan seçmeli 10 soru yöneltildi. Dört soru (1-4) vücut sıcaklığı ölçüm metotları, 5 soru (5-9) ateş tanımı ve 1 soru da ateşli çocuğa ilk müdahale konusunda idi. İstatistiksel analizler için SPSS (Statistical Package for Social Sciences) for Windows 20 programı kullanıldı. Oransal verilerin karşı1laștırılmasında Ki-Kare testi kullanıldı ve $p<0,05$ olan sonuçlar anlamlı olarak kabul edildi. Çalışma öncesinde Sakarya Üniversitesi Tıp Fakültesi Klinik Araştırmalar Etik Kurulu'ndan onay alınmıştır.

\section{BULGULAR}

Ankete 96 öğrenci katıldı. Kırk dört kişi birinci sınıf, 26 kiși ikinci sınıf, 17 kiși dördüncü sınıf ve 9 kişi beşinci sınıfta öğrenim görmekteydi.

\section{Tercih edilen termometre türü}

Öğrencilerin \% 44,8'i (43 kişi) çocuklarda vücut sıcaklığını ölçerken dijital termometre kullandığını belirtirken, $10(\% \quad 10,4)$ öğrenci 
civalı, 10 öğrenci infrared (alından) termometre kullandığını ifade etti (Şekil 1). Birden fazla termometre türünü kullandığını ifade eden 16 öğrenci mevcuttu ve bunlar farklı türleri tercih ediyordu. Ancak 11 öğrenci diğerleriyle birlikte infrared termometre, 10 öğrenci civalı ve 11 öğrenci de dijital termometre kullanıyordu. $\mathrm{Bu}$ durumda bir şekilde (tek başına ya da diğer türlerle birlikte) infrared termometreleri kullanan öğrenci sayısı 25 (\%26), civalı termometreleri kullanan öğrenci sayıs1 $20 \quad(\% 21)$ ve dijital termometreleri kullanan öğrenci sayısı 54 (\%56) idi. On üç $(\% 13,5)$ öğrenci ise hiç termometre kullanmadığını söyledi.

Hangi termometrenin vücut 1sısını daha doğru ölçtüğü sorusuna öğrencilerin 31'i dijital, 24'ü infrared ve 16's1 civalı termometre cevabinı verirken 19'u bu konuda fikri olmadığını söyledi (Şekil 2). Dijital termometre kullandığını belirten 43 öğrenciden 17 'si $(\% 39,5)$ bu termometrelerin daha doğru ölçüm yaptığını belirtirken 13 tanesi civalı ya da infrared termometrelerin daha doğru ölçtüğüne inanıyordu. 10 öğrenci (\%23) ise bu konuda fikri olmadığını ifade etti. Civalı veya infrared termometre kullandığını belirten gruplarda da doğru ölçüm konusunda benzer şekilde değişken cevaplar mevcuttu. Katılan öğrencilerden preklinik (1. ve 2. sinıflar) dönemde olanlarla diğerlerinin (4. ve 5. sinıflar) bilgileri de farklı idi. Daha doğru ölçen termometre konusunda preklinikteki öğrencilerin yaklaşık yarısı (31 kişi) dijital termometreleri işaretlerken diğer grubun yarısı (14 kişi) infrared termometreleri tercih etmişti $(\mathrm{p}<0,001)$. İkinci grupta hiç kimse dijital termometre şıkkını işaretlememişti.

\section{Tercih edilen ölçüm yeri}

Vücut sıcaklığının ölçüm yeriyle ilgili soruya 40 öğrenci $(\% 41,7)$ çocuklarda kullanılan ölçüm yerlerini tam olarak (koltuk altı, kulak, alın, ağız ve rektum) işaretleyerek cevap verdi. 2 öğrenci göğüsten de ölçülebileceğini söylerken 2 öğrenci de fikri olmadığını belirtti. Kalan 54 kiși ise ölçüm yeri olarak verilen seçeneklerin değişik kombinasyonlarını işaret etti. Ancak aksiller bölge \%96'sının, alın \%70'inin, kulak \%66'sının, ağız \%64'ünün ve rektum \%52'sinin seçenekleri arasında yer almaktaydi.

Siz çocuklarda vücut sıcaklığını nerelerden ölçüyorsunuz sorusuna ise \%30’u sadece aksiller bölgeyi, \% 21'i sadece alnı, \%15'i ise aksiller bölge ve alnı birlikte işaretleyerek cevap verdi. Rektumdan ölçtüğünü belirten sadece 3 kişi varken ölçümleri ağızdan da yaptığını bildiren 19 öğrenci vardı. Tek başına ya da diğer yerlerle birlikte aksiller yolu kullanan 66 kişi (\%68), benzer şekilde alnı kullanan 46 (\%48) öğrenci vardı. Ölçüm yeri konusunda preklinik ve klinik dönem öğrencileri arasında fark yoktu.

\section{Ateşin tanımı ve değerlendirilmesi}

96 öğrenciden 71’i (\%74) çocuklardaki ateș sınırının erişkinlerden farklı olduğunu ifade ederken, kalanların yarısı ateş değerlendirmesi için erişkinlerle çocukların aynı sınırlarla 
değerlendirildiğini, diğer yarısı ise bu konuda bir fikri olmadığını ifade etti.

Öğrencilerin yarıya yakını (\% 42,7) ateş demek için çocuklarda vücut sıcaklığının üst sınırı olarak $37,5{ }^{\circ} \mathrm{C}$ 'yi kabul etmekteydi. Yirmi kişi $(\% 20,8)$ $37{ }^{\circ} \mathrm{C}$, 15 kişi $(\% 15,6) 38{ }^{\circ} \mathrm{C}$ ve 12 kişi de (\%12.5) $36.5{ }^{\circ} \mathrm{C}^{\text {'yi }}$ ateş sınırı olarak belirtti (Şekil 3). Ancak katılanların \%76's1 vücut sıcaklığının ölçüldüğü yere göre değiştiğini de belirtmekteydi. Beş öğrenciden biri $(\% 18,8)$ ölçüm yerine göre vücut sicaklığının değişmediğini düşünüyordu.

Ölçüm yerine göre vücut sıcaklığının değiştiğini belirten 73 öğrenci arasında yapılan değerlendirmede; 19 kişi (\%26) rektum, 18 kişi $(\% 24,7)$ koltuk altı ve 15 kişi $(\% 20,5)$ kulaktan yapılan ölçümün en doğru sonucu vereceğini belirtti. Vücut sıcaklığının en yüksek ölçüldüğü yer olarak çoğunluk (\%52) rektumu işaretlerken $21(\% 28,8)$ kişi fikri olmadığını söyledi. Ölçüm yerine göre vücut sıcaklığının yüksekten alçağa doğru sıralanmasında \%65 öğrencinin fikri yoktu. Sadece 8 (\%11) öğrenci en yüksek ölçümün rektumdan ve en düşük ölçümün koltuk altından yapılacağını belirtmişti.

\section{Ateşli çocuğa ilk müdahale}

Yüksek ateş saptanan çocuğa ilk müdahale olarak antipiretik ilaç veren veya soğuk suyla duş öneren hemen hemen yoktu. İlk müdahale tercihleri giysileri çıkarma, 1lık suyla duş ve alın-koltuk altına pansuman önerileri arasında benzer şekilde dağılmaktaydı (Tablo 1).

\section{TARTIŞMA VE SONUÇ}

Çocukluk çağında hekime başvurma nedenleri arasında ilk siralarda yer alan ateş, vücut sıcaklığının normal sınırların üzerine çıkması olarak bilinmektedir. Ancak vücut sıcaklığının ölçüldüğü yer ve kullanılan termometre türüne göre bazı farklılıklar göstermesi, ateşin tanımı konusunda farklı algılara yol açmaktadır. Nitekim tıp fakültesi öğrencileri arasında yaptığımız bu anket çalışması da günlük pratikte gözlediğimiz bu farklılıkları ortaya koymayı amaçlamaktadır. Günümüzde vücut sıcaklığını ölçmede kullanılan belli başlı termometre türleri dijital, civalı ve infrared (kulak zarı veya alından ölçen) termometrelerdir. Ülkemizde sağlık hizmeti veren kurumlarda infrared termometreler son y1llarda daha yaygın kullanılmasına karşın aileler tarafindan en çok kullanılan termometre türü dijital termometrelerdir. Bunu civalı ve giderek artan oranda infrared termometreler izlemektedir. ${ }^{4,5}$ Bizim çalışma grubumuzda da en çok kullanılan dijital termometreler idi. Günlük pratikte hastanenin tüm birimlerinde infrared termometrelerin kullanıldığı göz önüne alınırsa, bu tercihin öğrencilerin daha çok aileden gelen eski alışkanlıklarını yansıttığını söyleyebiliriz. Katılanların çoğunluğu preklinik dönemde öğrenim gördüğü için bu anlaşılabilir bir tutum olacaktır. Ancak yine de dijital termometreyi tercih edenlerin oranı $(\% 44,8)$ yukarıdaki çalışmalarda bildirilenlerden (\%60-80) daha düşük düzeydeydi. 
İlginç olan hangi termometre türünün daha sağlıklı ölçüm yaptığ 1 sorusuna verilen yanıtlardı. Öğrencilerin yaklaşık \%20'sinin bu konuda bir fikri yoktu. Dijital termometre kullananların sadece \%40’1 bu termometrelerin daha doğru ölçüm yaptığına inanmaktaydı. Bu sonuçlar da, termometre tercihinin çoğunlukla bilinçli bir tercihe dayanmadığını ima etmektedir. Uygun termometre ve ölçüm yeri konusunda ailelerin de emin olmadıkları görülmekte ve bu açıdan bizim sonuçlarımızla benzerlik göstermektedir. ${ }^{4}$ Ancak termometre konusunda preklinik ve klinik dönem öğrencileri arasındaki tercihlerin farklı olması, sonrakilerin infrared termometre yönünde tercih belirtmeleri, büyük olasılıkla hastanemizdeki kliniklerde bu tür termometrelerin kullanılmasından kaynaklanmaktadır.

Çocuklarda vücut sıcaklığını ölçmek için klasik olarak oral, aksiller ve rektal yolla birlikte giderek artan oranda timpanik membran ve temporal arter de kullanılmaktadır. İç (core) vücut 1sisinı yansitmada rektal yolla yapilan ölçüm altın standart olarak kabul edilmektedir. Ancak son yıllarda yapılan çalışmalar aksi görüşlere rağmen, infrared termometre ile timpanik membran ya da temporal arterden (alından) yapılan ölçümlerin iç vücut 1sısı ile çok iyi korele olduğunu ve rektal ölçüme alternatif olabileceğini göstermektedir. ${ }^{3,6-9}$ Kullanılan termometre türleriyle de ilişkili olan bu lokalizasyonların her birinin kendine özgü avantaj ve dezavantajları bulunmaktadır. ${ }^{10,11}$ Bundan dolayı da ideal ölçüm yeri ve metodu konusunda bazen yaş gruplarına göre de değișen farklı önerilerde bulunulmaktadır. ${ }^{12}$ Dijital termometre ile aksiller bölgeden ölçüm ebeveynler tarafindan en sik tercih edilen yol olduğu kadar rehberlerde de ilk sıralarda önerilen metotlardandır. ${ }^{4,13}$ Çalışmaya katılan öğrencilerin yaklaşık \%42'si vücut sıcaklığının ölçüm yerlerini doğru ve eksiksiz biliyordu. En sik kullanılan ölçüm yeri olarak aksiller bölge belirtilmişti. Ancak öğrencilerin yaklaşık yarısı vücut sicaklığının rektumdan da ölçüldüğünü belirtmesine rağmen sadece \%3'ü rektal yolla ölçüm yapmıştı. Rektal yol günlük pratikte kliniklerde kullanılmadığ 1 için bu sonuç normal karşılanabilir. Ancak aynı şekilde rutin uygulama arasında yer almamasına rağmen, oral yolla ölçüm yaptığını bildiren 19 (\%20) öğrencinin olması ilginçti.

Ölçüldüğü yere göre vücut 1sısının normal değerleri değişmektedir. ${ }^{9,14}$ Ayrıca aynı kişide gün içinde de değişiklikler gözlenebilmekte, hatta yaşlara göre bile farklılık gösterdiği bilinmektedir. ${ }^{13-15}$ Bundan dolayı da ateş tanımı farklı kaynaklarda farklı şekillerde verilebilmektedir. Ancak genel olarak, uygun şekilde giydirilmiş bir çocuğun, 30 dakikalık istirahat sonrasında rektal yolla ölçülen vücut sıcaklığının $\geq 38^{\circ} \mathrm{C}$ olması ateş olarak tanımlanmaktadır. Eş zamanlı olarak oral yolla ölçülen vücut sıcaklığı rektal sıcaklıktan genellikle $0,6^{\circ} \mathrm{C}$, aksiller bölgeden ölçülen ise $1,1^{\circ} \mathrm{C}$ daha düșük tespit edilmektedir. ${ }^{6,16} \mathrm{Bu}$ çalışmada da katılanların \%74'ü çocuklardaki 
ateş tanımının erişkinlerden farklı olduğunu ifade ederken, vücut sıcaklığının üst sınırı konusunda farklı fikirler mevcuttu. Öğrencilerin sadece $\% 15^{\prime} \mathrm{i} \quad 38^{\circ} \mathrm{C}$ 'nin üzerini ateş olarak değerlendiriyordu. Vücut sıcaklığının ölçüldüğü yere göre değişebileceğini ifade edenlerin içerisinde, en doğru ölçümün rektal yolla yapılabileceğini belirtenlerin oranı ise \%26 idi. $\mathrm{Bu}$ farklılığın bir sebebi ilgili soruda ölçüm yerinin belirtilmemesi olabileceği gibi literatürdeki tanımların farklılığı da olabilir. Ayrıca ateş tanımı rektal ölçüm üzerinden yapılırken günlük pratikte çoğunlukla aksiller yol kullanılmakta ya da kliniklerde infrared termometrelerle ölçüm yapılmaktadır. $\mathrm{Bu}$ sonuçlar, ateş tanımının günlük pratikte kullanılan metotlara göre güncellenmesi ve eğitimde bunların vurgulanması gereğini ortaya çıkarmaktadır. Zira tetkik ve tedaviye yönelik girişimlerde rutindeki ölçümler kriter alınmakta, hiçbir zaman ateşin varlığı rektal ölçümle teyit edilmemektedir.

Ateşli çocukta vücut 1sısını düşürmek için kullanılan fiziksel uygulamalar (duş aldırma, 1lık veya soğuk suyla pansuman, buz torbası, cilde alkol uygulanması vs.) hipertermi dışında önerilmemektedir. Antipiretikler ise ateşle birlikte huzursuzluk, aktivite veya iştahta azalma ve uyku düzeninin bozulması gibi bulguların varlığında önerilmektedir. ${ }^{12-14}$

Bizim çalışmamızda öğrencilerin yarısı ilk müdahale olarak 1lı suyla duş veya lokal pansuman, $\% 35^{\prime} \mathrm{i}$ ise giysilerin çıkarılmasını önermekte idi.
Antipiretik verilmesini önerenlerin oranı ise $\% 4$ gibi çok düşüktü. Verilen yanıtlar preklinik ve klinik dönem öğrencileri arasında benzerlik göstermekteydi. Yıldırım ve ark. $^{5}$ yaptıkları çalışmada da annelerin önemli bir kısmının (\%60), ateşli çocukta ilk olarak giysilerini çıkardıkları veya cilde soğuk uygulamada bulunduklarını, yaklaşık \%28'inin ise ilk uygulama olarak antipiretik verdiklerini bildirmektedirler. Polat ve ark. $^{4}$ ise ailelerin \%72'sinin ateşi düşürmek için 1lık suyla duş (\%68) ve giysileri çıkarma gibi fiziksel uygulamalar yaptıklarını, bunların bir kısmının (\%20) da soğuk suyla duş, cilde sirke ve alkol sürülmesi gibi uygun olmayan metotlar kullandıklarını rapor etmektedirler.

$\mathrm{Bu}$ çalışmanın en önemli kısıtlılığı çalışmaya katılan öğrencilerin farklı sınıflarda olmaları ve önemli bir kısmının birinci sınıfta olmasıdır. Her sınıftan yeterli sayıda öğrenci olması durumunda sınıflar arasındaki farkı ve eğitimin yeterliliğini değerlendirmek mümkün olabilirdi.

Sonuç olarak, çocuk hastaların muayenesi sirasında en sik gerek duyulan vital bulgulardan biri olan vücut sıcaklığının ölçüm tekniği, değerlendirilmesi ve yönetimi konusunda, tıp fakültesi öğrencilerinin bilgi ve tutumlarının yetersiz olduğu gözlendi. Ancak bu sonuç, çalışmaya katılan öğrencilerin önemli bir kısmının bu konuda henüz eğitim almamış olma ihtimali bulunan birinci sınıf öğrencilerinden oluștuğu düşünülerek değerlendirilmelidir. 


\section{KAYNAKLAR}

1. Berkowitz CD. Fever. In: Tintinalli JE, Kelen GD, Stapezynski JS (eds). Emergency Medicine: A comprehensive study guide. 6th Ed. United States of America, Mc Graw Hill; 2004: 749-751.

2. Batra P, Saha A, Faridi MM. Thermometry in children. J Emerg Trauma Shock. 2012;5(3):246-249.

3. Paes BF, Vermeulen K, Brohet RM, van der Ploeg T, de Winter JP. Accuracy of tympanic and infrared skin thermometers in children. Arch Dis Child. 2010;95:974.

4. Polat M, Kara S, Tezer H, Tapısız A, Derinöz O, Dolgun A. A current analysis of caregivers' approaches to fever and antipyretic usage. J Infect Dev Ctries. 2014;8(3):365-371.

5. Yildırım A, Bozaykut A, Dalkan C . 6 Ay -6 Yaş Arası Yüksek Ateşli Çocukların Annelerinin Ateş Bilinç Seviyesinin Değerlendirilmesi. Türkiye Çocuk Hast Derg/Turkish J Pediatr Dis. 2014;4:201-207.

6. Alpern ER, Henretig FM. Fever. In: Fleisher GR, Ludwig S, Bachur RG, ve ark,(eds). Textbook of Pediatric Emergency Medicine. $6^{\text {th }}$ Ed., Philadelphia, Lippincott, Williams \& Wilkins; 2010: 266-276.

7. Zhen C, Xia Z, Long L, Pu Y. Accuracy of infrared ear thermometry in children: a metaanalysis and systematic review. Clin Pediatr (Phila). 2014;53(12):1158-1165.

8. Hamilton PA, Marcos LS, Secic M. Performance of infrared ear and forehead thermometers: a comparative study in 205 febrile and afebrile children. J Clin Nurs. 2013;22(17-18):2509-2518.

9. Hoffman RJ, Etwaru K, Dreisinger $\mathrm{N}$, Khokhar A, Husk G. Comparison of temporal artery thermometry and rectal thermometry in febrile pediatric emergency department patients. Pediatr Emerg Care. 2013;29(3):301304.

10. Ward MA. Fever: Pathogenesis and treatment. In: Cherry JD, Harrison GJ, Kaplan SL, ve ark. (eds). Feigin and Cherry's Textbook of Pediatric Infectious Diseases, $7^{\text {th }}$ Ed. Philadelphia, Elsevier Saunders; 2014: 83.

11. Rush M, Wetherall A. Temperature measurement: practice guidelines. Paediatr Nurs. 2003;15(9):25-28.

12. Chiappini E, Principi N, Longhi R, et al; Writing Committee of the Italian Pediatric Society Panel for the Management of Fever in Children. Management of fever in children: summary of the Italian Pediatric Society guidelines. Clin Ther. 2009;31(8):1826-1843.

13. National Collaborating Centre for Women's and Children's Health (UK). Feverish Illness in Children: Assessment and Initial Management in Children Younger Than 5 Years. London: Royal College of Obstetricians \& Gynaecologists (UK); $2013 \quad$ May. http://guidance.nice.org.uk/CG160 (Accessed on July 20, 2015).

14. Ward MA, Hannemann NL. Fever: Pathogenesis and treatment. In: Cherry JD, 
Harrison G, Kaplan SL, et al (eds). Feigin and Cherry's Textbook of Pediatric Infectious

Diseases, 8th ed, Philadelphia, Elsevier; 2018: p.52.

15. Brown AJS. Assessing the sick child. In:

Edward Alan Glasper, Gillian McEwing, Jim Richardson (eds). Oxford Handbook of Children's and Young People's Nursing,
Newyork, Oxford University Press; 2007: 89103.

16. Nield LS, Kamat D. Fever. In: Kliegman RM , Stanton BF, St. Geme JW, Schor NF, Behrman RE (eds). Nelson Textbook of Pediatrics, $20^{\text {th }} \quad$ Ed., Philadelphia, Elsevier/Saunders; 2016: 1277-1279. 
Tablo 1. Yüksek ateş saptanan çocuğa ilk müdahale tercihleri.

\begin{tabular}{lc}
\hline İlk müdahale & Sayı (\%) \\
\hline Giysileri çıkarma & $35(35,4)$ \\
Antipiretik verme & $4(4,2)$ \\
Alın-koltuk altına pansuman & $20(20,8)$ \\
Ilık suyla duş & $29(30,2)$ \\
Soğuk suyla duş & $2(2,1)$ \\
\hline
\end{tabular}




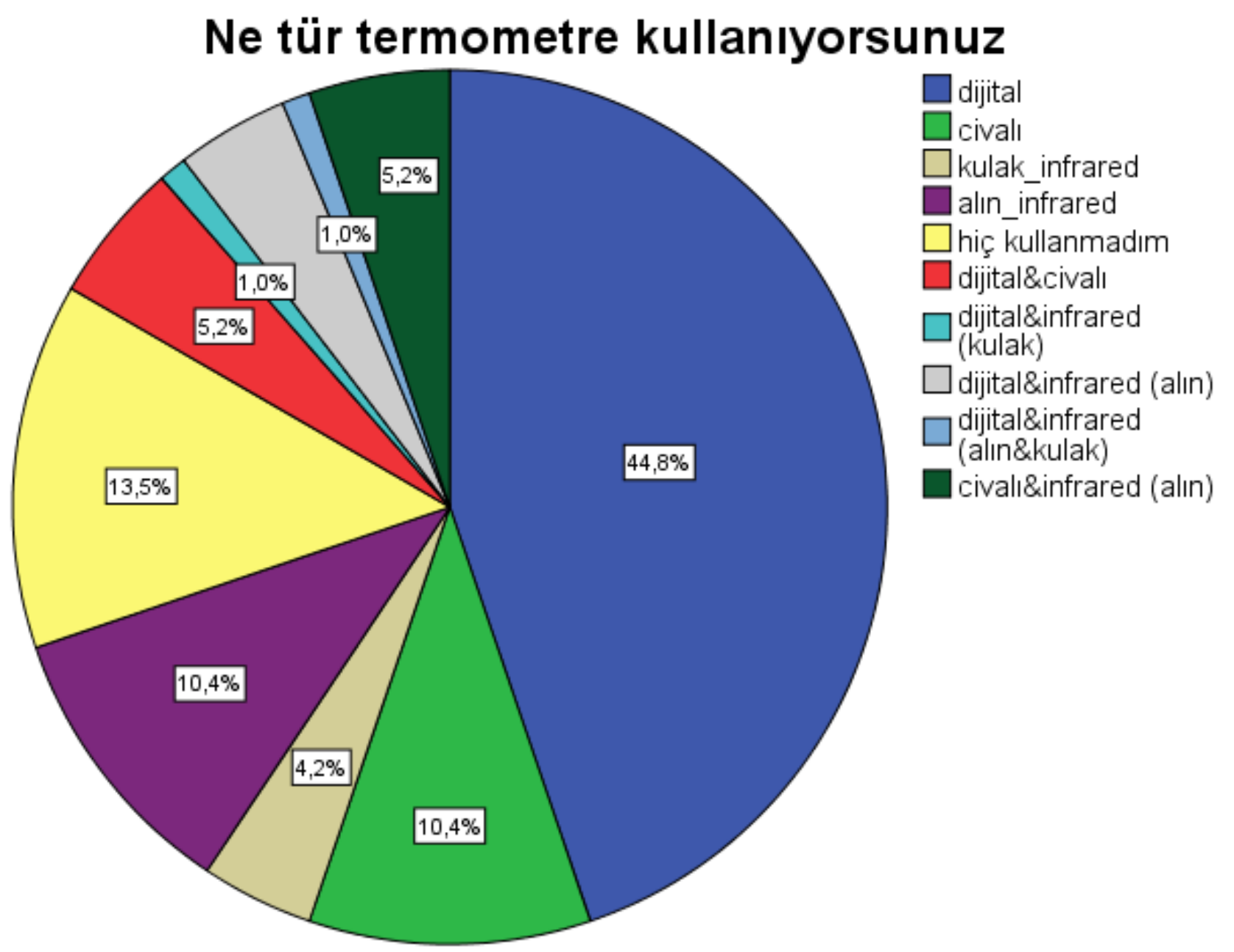

Şekil 1. Kullanılan termometre türü. 


\section{Hangi termometre daha doğru ölçer}

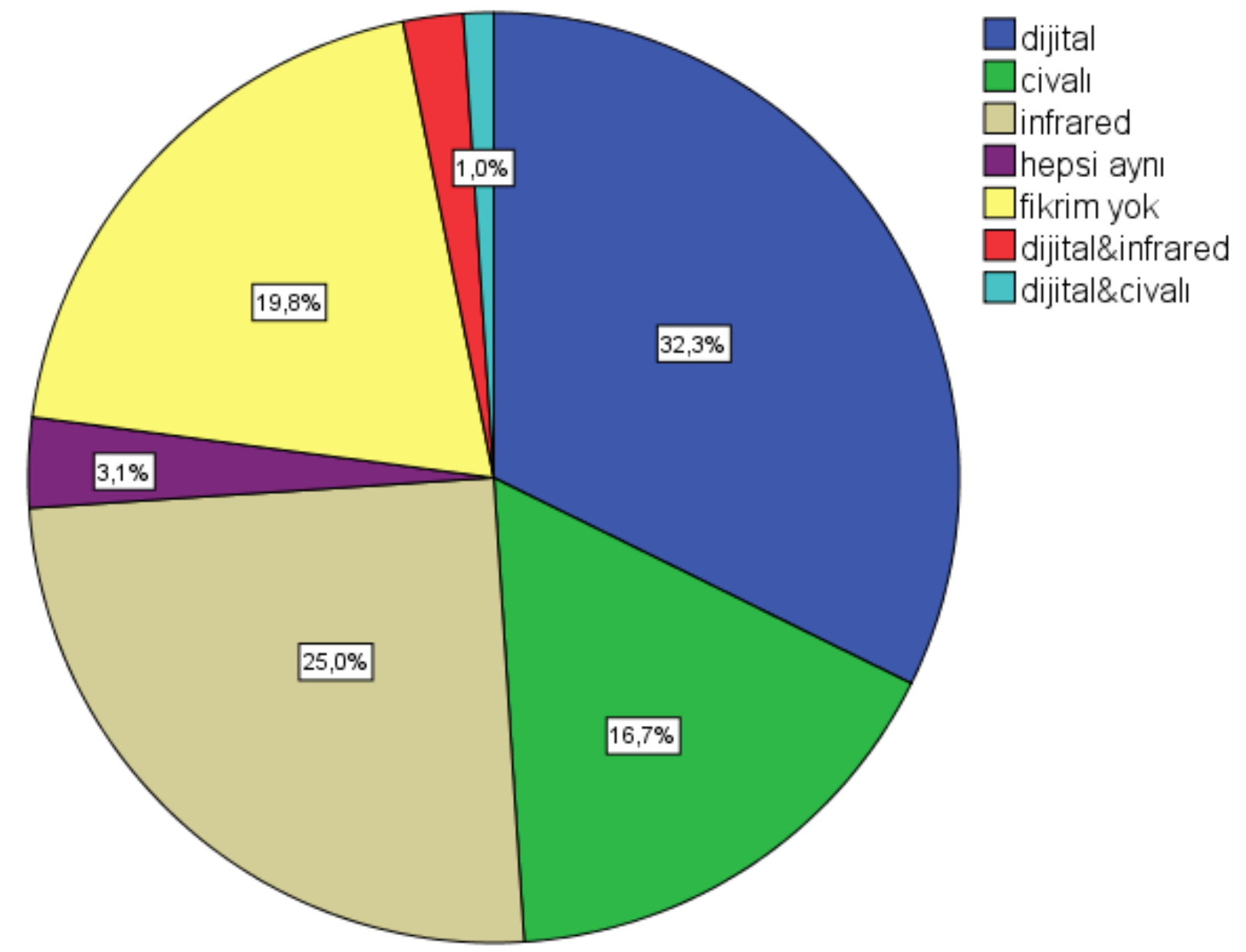

Şekil 2. Katılanların, hangi tür termometrenin vücut sıcaklığını daha doğru ölçtüğüne dair görüşleri. 


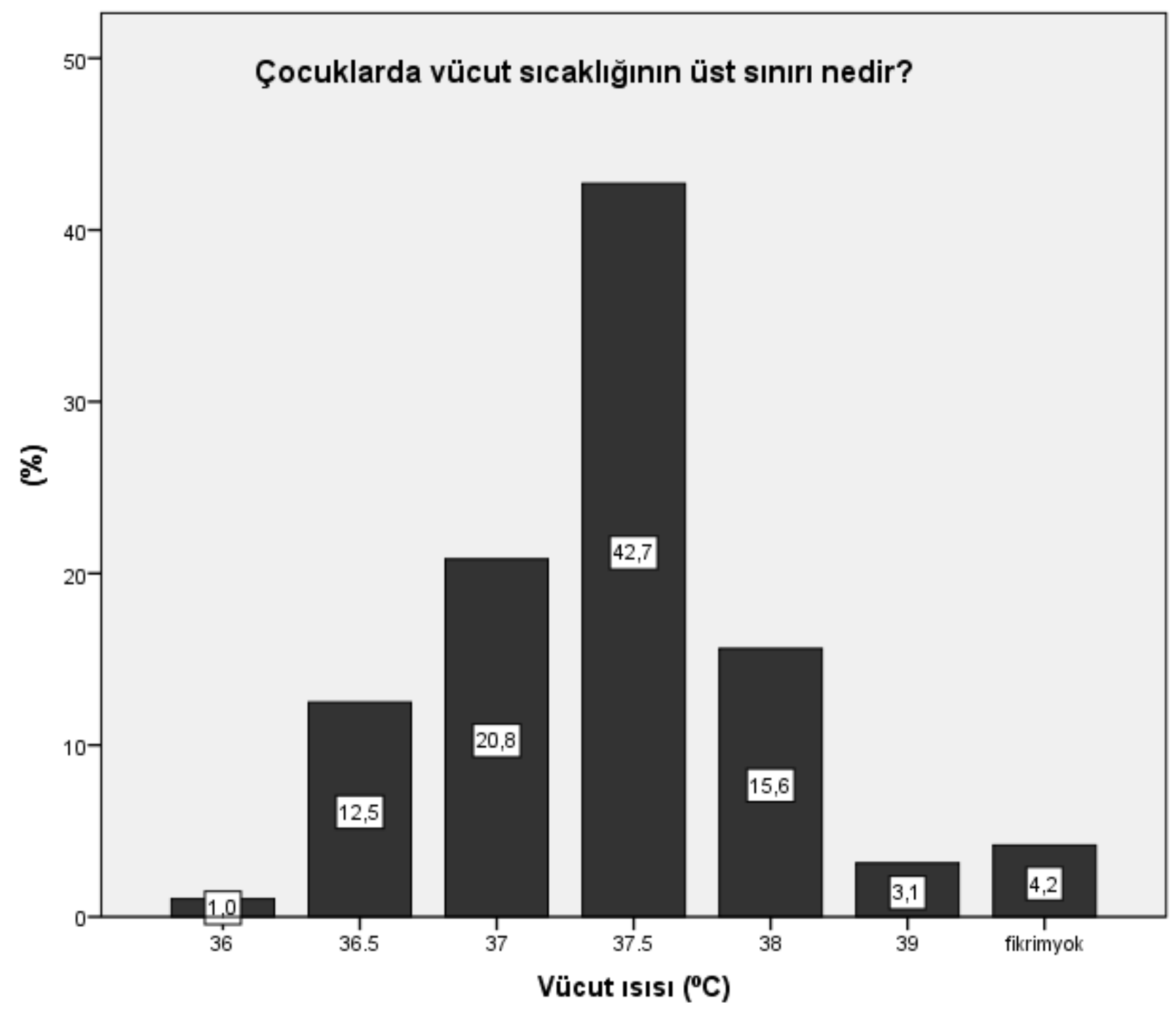

Şekil 3. Katılanların, çocuklarda normal vücut sıcaklığının üst sınırı ile ilgili görüşleri. 